\title{
EFFECT OF ACTIVITY-BASED AND CHALLENGE-BASED LEARNING APPROACHES ON TECHNICAL COLLEGES STUDENTS' PSYCHOMOTOR ACHIEVEMENT IN FURNITURE CRAFT TECHNOLOGY
}

\author{
${ }^{1}$ Hassan A.M and ${ }^{2}$ Abdullahi S.M \\ ${ }^{1}$ Dept. of Industrial and Technology Education, School of Science and Technology Education, \\ Federal University of Technology, Minna, Nigeria \\ ${ }^{2}$ Scientific Equipment Development Institute, Minna, Nigeria \\ Email: yabhass@yahoo.com
}

\begin{abstract}
This study adopted the quasi-experimental research design, precisely, pre-test, post-test nonequivalent control group design. The population for the study was 210 National Technical Certificate (NTC II) furniture craft technology students (175 males and 35 females) in Technical Colleges. This study was carried out in Zamfara and Katsina State. The analysis was guided by three research questions and three hypotheses at 0.05 level of significance. The data were obtained with Furniture craft technology Cognitive Achievement Test (FTCAT) and Furniture craft technology Interest Inventory (FTII). The lesson plan, FTCAT, and FTII were subjected to face and content validation by three experts. The instrument was trial tested on a sample of 22 NTC II furniture craft technology students of Government Technical College FCT-Abuja. Kuder-Richardson 20(KR20) and the Pearson product-moment correlation coefficient were utilized to establish the coefficient of internal consistency and stability of the FTCAT. The values were found to be 0.72 and 0.81 respectively. Data obtained from the administration of the instrument was examined with mean to answer the research questions and Analysis of Covariance (ANCOVA) statistic was used to test the hypotheses. The results showed that the Challenge-based learning approach is more successful in enhancing the students' achievement in furniture craft technology than the Activity-based learning approach. It was recommended that the Ministry of Education and National Board for Technical Education (NBTE) should organize workshops, seminars and in-service training for technical teachers regularly
\end{abstract}

Keywords: achievement, activity-based, challenge-based, furniture craft, interest

\section{INTRODUCTION}

Furniture craft becomes one of the skills in Nigerian vocational schools intended to accommodate the market demands of craftsmen to repair, manufacture and restore all types of furniture pieces. Furniture craft in technical colleges is oriented to providing technicians and craftsmen equipped with expertise, personality, and skills to increase production and growth in the furniture craft businesses. The craftsmen and technicians are needed to design, manufacture, and repair modem furniture. Technical colleges accept and prepare male and female students in Furniture craft and other vocational fields.

Federal Republic of Nigeria [1], stressed that the National Business and Technical Examination Board (NABTEB) awards National Technical Certificate and Advanced
National Technical Certificate to the graduate of Furniture Craft. Furniture Craft is all about making use of wood to solve human problems. Furniture craft is categorized as a vocational education program at a technical college [2]. Vocational education has the main function to train students for occupation in recognized careers [3]. Furthermore, Francis [4] described vocational education as vocational-technical training or retraining delivered in schools or classrooms under public supervision and control, or under arrangements with a state board or a local educational institution.

It is carried out as part of a system designed to prepare the participants to obtained opportunities as semi-skilled workers or technicians or sub-professionals in advanced professions and new and emerging careers or to prepare people for jobs in an advanced education program for quality academic 
achievement of furniture craft technology students. Vocational education cannot be separated from employment in the workplace [5].

The achievement of furniture craft technology students' in NABTEB especially that of $2015 / 2016,2016 / 2017,2017 / 2018$ has not been encouraging. These can be seen in the distribution of students' academic achievement by years of study in the colleges within the area under study. This repeated poor academic performance most frequently decreases the motivation of the students and may result in poor comprehension of furniture craft technology and also add other negative effects on the entire learning goals. Students often dislike a subject that reports a high rate of test failure and is highly reliant on performance and motivation. Regarding this low student achievement in the field of furniture craft technology, one is supposed to be concerned. However, the learning process in furniture craft technology could be improved by implementing teaching and learning strategies grounded in a problem-based approach to learning.

Problem-based learning (PBL) is one of the constructivist learning approaches that present a Relevant contextualized practicalworld scenario, offering learning resources, direction, and instruction as students gain knowledge of content and problem-solving skills [6]. It focused on student-centered, selfdirected integrated and contextual learning. Problem-based learning allows students to deliberately investigate other information resources besides the teacher, namely primary texts, reference materials, and community members, and build on expertise from multiple subject areas.

Consequently, Ogbuanya [6] proposed that students have to take initiative for their education and that teachers be portrayed as advisors and less as resources. Hence, teaching approaches that are based in PBL may be a reliable method to convey both theory and practical woodwork. It enables the students to understand how to study and reduces the guidance of the teacher as the students are actively engaged.

The challenge-based learning and activity-based approaches are common among teaching and learning methods rooted in problem-based learning. Challenge Based Learning (CBL) is an immersive, multidisciplinary approach to teaching and learning that allows students to use the technologies they use to solve real-world challenges in their everyday lives [7].The authors established that Challenge-Based Learning arises with a new idea and cascades into the following: the critical question; the challenge; directing questions, activities, and resources; deciding and formulating the answer; having the initiative by implementing the answer.

Further, Johnson et al. [7] emphasized that CBL draws on problem-based learning practice, where students collaborate on realworld issues in collaborative teams, but with main distinctions that bring a lot of value to students. A mission statement is at the core of CBL which ultimately involves students and encourages them to study their problem, conceptualize ideas and solutions that are both plausible and practical in terms of time and resources and then develop and enforce one of the solutions to resolve the challenge in respects that can be seen and assessed by both themselves and others. Therefore, challengebased teaching and learning approach is a teaching approach where students use technology to research and find a solution to problems.

Even though teachers' participation is essential in the CBL cycle, its nature evolves as students move through their phases. Early on when the teacher presents CBL to students and establishes the challenge, the teacher takes decisions, shares information, demonstrates skills, and addresses questions about how the process progresses and what students are required to do. 
Students are responsible for preparing and conducting their work in the middle stages, and the teacher acts mainly as a project coordinator and tutor collaborating with the students, guiding them through the difficult spots and keeping them on track. Students are actively involved in their work in the latter stages while the teacher confirms they have acquired the essential knowledge and skills through effective evaluations. Finally, the teacher transits into the function of the project manager assisting the students in implementing, reviewing, and publishing their solutions and findings. Challenge-based teaching/learning approach like Activity - Based teaching/ learning is geared towards improving students' achievement in the $21^{\text {st }}$-century classrooms. Though, this is yet to be verified in furniture craft technology[3].

In the Activity-based teaching approach, the Cards substituted the textbook. The cards are created based on units in the textbooks. The cards are used to present the topic, to learn it, to reinforce it and to evaluate it. The cards provide individual and group tasks. In card boxes, the cards are set in order of steps on a ladder. Icons are illustrating each stage and each task inside it. Within each class, a ladder for the subject is shown on a map. Students are required to identify which card they are on and to find the relevant cards from the systematically organized card boxes in the class with the corresponding icon labels.

Students work either individually or in groups. Sometimes, students at higher levels help students at lower levels. There is a decrease of the teacher-student ratio to $1: 1$ where the teacher attends to only one child at a time. The activity-Based and CBL approach earlier discussed seems capable of improving students' academic performance and retention of learning in woodwork technology since both are learner-centered. However, it not yet known which of these teaching methods will be better in enhancing students' performance in furniture craft technology.
Psychomotor achievement simply relates to students' achievement in practical tasks. Therefore in this research, psychomotor achievement refers to the achievement of students in Woodwork technology practical task which is usually represented by a score or mark obtained in a performance test. Okoro [3] clarified that the performance evaluation requires the use of equipment and resources in a clear measure of the number of practical skills the student owns. The cognitive and psychomotor performance of students is determined by several factors among which are the instructional method and the learner's ability. However, it is also observed that students' cognitive and psychomotor achievement may also be influenced by the gender of the student.

Gender corresponds to the features by which humans identify male and female, whether biologically or socially influenced [8]. Besides, gender may be defined as the roles, attitudes, activities, and characteristics acceptable for men and women that are socially created by culture.

Disparities typically occur in the performance rates of males and females. Thus, this study will evaluate if the psychomotor achievement of students and interest in furniture craft technology will represent the gender of students after exposure to challenge-based learning teaching approach and activity-based learning approach [3].

Interest is an important factor in learning, it is viewed as the feeling that an individual has when he or she wants to know or learn more about something such as furniture craft technology[9]. Obodo [10] argued that interest is the attraction that drives a person to react to a certain stimulus. Stated differently, if a certain stimulation (e.g. teaching method or subject matter) is interesting and arousing or exciting, a child grows interest. This indicates that if the student is interested in a certain class, he will have to focus as a lesson progresses further. Harbor-Peters [11] asserted that interest is generated from the desire to learn intentionally. 
Interest is an effective learning factor because if students have a strong interest in the subject, they not only value learning the subject but will also gain fulfillment from the subject's knowledge. Interest is perceived concerning the internal state of mind or reactions to the external environment or predisposition to experience. Interest may also be viewed as the readiness to react towards or against a situation, person or things in a particular manner, e.g. with love or hate fear or resentment to a particular degree or intensity.

Hence, a furniture craftsman's skills in the creation and repair of woodwork items can be improved by teaching methods such as Challenge-Based or Activity - Based Learning approach. The aim of the study would, therefore, to figure out which of these methods would be more beneficial in enhancing the psychomotor performance of the students and their interest in furniture craft technology.

Despite the huge investment in the Technical College system by the successive Nigerian government aimed at improving the reputation and achievement of students at the Technical College, the students' learning outcomes in furniture craft technology trade is not encouraging.

The Federal Ministry of Education has detected some of the reasons accountable to the high failure rate of Technical College students in NABTEB tests, notably in the furniture craft sector, include inadequate teaching methodology in technical colleges. It was further reported that the teacher-centered method is the dominant teaching strategy employed by the technical teachers for the curriculum application.

The implementation of teacher-centered methods causes the insufficient use of variations of instructional method and teaching techniques and failure of teachers to successfully execute the program to gradually boost the interest, participation, and engagement of students in learning. The weaknesses in the teacher-centered teaching method may cause weak academic accomplishment of furniture craft students in a public test. Consequently, the teaching of furniture craft technology requires a shift in methods and techniques to allow students in technical colleges to gain optimum knowledge and skills for the world of work, better achievement in public examinations and further studies.

The problem of this study, therefore, is whether an activity-based and challenge-based learning approach putting into consideration, the influence of gender enhances students psychomotor achievement and interest in furniture craft technology in technical colleges in Zamfara and Katsina State. The objectives of this study were to examine the impacts of Challenge-based and Activity-based learning approaches on the students' interest, psychomotor achievement and the interest of students based on gender in furniture craft technology.

\section{METHOD}

A quasi-experimental research design was used for this study. The study was carried out in Zamfara and Katsina State of Nigeria. The population for this study consists of 210 NTC II students (175 males and 35 females) of furniture craft in the nine Technical Colleges offering furniture craft trade in Zamfara and Katsina State. The sample size for this study was 68 furniture craft NTC II students: 39 students that consisted of 32 males and 7 females participated in the Challenge-based learning approach while 29 students that consisted of 24 males and 5 females participated in the Activity-based learning approach. A purposive sampling technique was used for selection of two colleges from the six Technical colleges for this study thereafter, a simple random technique was equally used to allocate one college each to Challenge-based and Activity-based learning approaches respectively.

The instruments used for data collection in this study were Furniture craft Technology 
Cognitive Achievement Test (FTCAT) and Furniture craft Technology Interest Inventory (FTII). The Furniture craft Technology Cognitive Achievement Test (FTCAT) and Furniture craft Technology Interest Inventory (FTII) were validated by one subject expert in furniture craft technology with National Business and Technical Examination Board (NABTEB) and two experienced furniture craft teacher drawn from Technical Colleges. A trial test of the instrument was carried out to determine the coefficient of stability of the Furniture craft Technology Cognitive Achievement Test (FTCAT) using the testretest reliability technique.

The instrument was administered on twenty-two NTC II Furniture craft Technology Students in Government Technical College, FCT-Abuja. The reliability coefficient of the FTCAT was determined using the Pearson product-moment correlating coefficient. The reliability coefficient of 0.81 was gotten showing that FTCAT was stable. The FTII was administered on an equivalent sample of NTC II furniture craft students in Government Technical College, FCT-Abuja. The reliability coefficient for the furniture craft interest inventory was determined to be 0.72 .

The Furniture craft teachers administered the pre-test to both the Challenge-based and Activity-based learning approaches in their respective colleges. During the pretest, the furniture craft technology cognitive achievement test (FTCAT) and furniture craft technology interest inventory (FTII) was administered to both the Challenge-based and Activity-based learning approaches respectively. The data collected from the administration of pre-test and post-test were analyzed using mean to answer the research questions. The standard deviation shows the closeness of the results to the mean. The pretest, post-test mean gain of each of the groups was compared to determine the group that performed better. The null hypotheses were tested using Analysis of Covariance (ANCOVA) at the level of significance of 0.05

\section{RESULTS AND DISCUSSION}

Table 1 shows that pre-interest mean and standard deviation scores for students taught furniture craft using Challenge-based learning are 2.84 and 0.32 , while those taught furniture craft using Activity-based learning are 2.93 and 0.29 . This shows that both groups were almost in the same interest score before the experimental treatment. However, posttest interest mean and standard deviation scores for the Challenge-based group are 3.01 and 0.42 , whereas the posttest means and standard deviation scores for the Activity-based group are 3.03 and 0.37 . This shows that the group taught using Challenge-based learning has a mean gain score of 0.17 , whereas the Activitybased learning group has a mean gain score of 0.10 .

$\underline{\text { Table 1.Mean and Standard Deviation Interest Scores of Students Taught Furniture Craft on Method }}$

\begin{tabular}{ccccccc}
\hline & \multicolumn{3}{c}{ Pre-interest } & \multicolumn{2}{c}{ Post-interest } & \multicolumn{2}{c}{ Mean } \\
Method & $\mathrm{N}$ & Mean & SD & Mean & SD & gain/loss \\
\hline Challenge-based learning & 39 & 2.84 & 0.32 & 3.01 & 0.42 & +0.17 \\
Activity-based learning & 29 & 2.93 & 0.29 & 3.03 & 0.37 & +0.10 \\
\hline
\end{tabular}

The first hypothesis in this study was there is no significant difference between the students' interest in furniture craft technology who are treated with challenge-based and those treated with the activity-based learning approach. Table 2 shows that F-ratio (0.223) with associate probability (sig (2-tailed) $(p=0.638)$ under method is greater than significant level (0.05) postulated. Hence, the alternative hypothesis was upheld. Therefore, there is no significant difference between the mean score of students' interest taught furniture craft with Challenge-based learning and those taught with Activity-based learning. 
Table 2. Analysis of Covariance (ANCOVA) of Students' Mean Interest in Furniture Craft on Method Tests of BetweenSubjects Effects

\begin{tabular}{lccccc}
\hline \begin{tabular}{c} 
Dependent Variable: post interest \\
\multicolumn{1}{c}{ Source }
\end{tabular} & Type III Sum of Squares & df & Mean Square & F & Sig. \\
\hline Corrected Method & & & & & \\
Intercept & $.346^{\mathrm{a}}$ & 2 & .173 & 1.070 & .349 \\
Preinterest & 8.738 & 1 & 8.738 & 54.056 & .000 \\
Method & .226 & 1 & .226 & 1.396 & .242 \\
Error & .036 & 1 & .036 & .223 & .638 \\
Total & 10.507 & 65 & .162 & & \\
Corrected Total & 612.547 & 68 & & & \\
\hline
\end{tabular}

a. R Squared $=.032$ (Adjusted R Squared $=.002$ )

Table 3 reveals that pretest achievement mean and standard deviation scores for male students in the Challenge-based group are 35.59 and 8.18 , while that of females in the same group is 31.43 and 10.99 . Also posttest achievement mean and standard deviation scores for males in Challenge-based group are 63.91 and 22.09 with a mean gain score of 28.32 , while that of females in the same group are 69.57 and 25.98 with a mean gain score of 38.14 .

Similarly, pretest achievement mean and standard deviation scores for males in the Activity-based group are 27.92 and 11.82, while that of females in the same group is 25.80 and 7.39. Again, posttest mean and standard deviation scores for males in the Activitybased's group are 31.79 and 6.59 with a mean gain score of 3.87 , while that of females in the same group are 26.20 and 8.67 with a mean gain score of 0.40 .

The second hypothesis was there is no significant difference in the students' achievement in furniture craft technology who treated with Challenge-based and those treated with activity-based learning approaches based on gender. Table 4 indicates that F-ratio (0.066) with associate probability (sig (2-tailed) $(p=0.799)$ under gender being greater than the significant level (0.05) postulated. Hence, the alternative hypothesis was upheld. Therefore, there is no significant difference between the mean achievement scores of students taught furniture craft with Challenge-based learning and those taught with Activity-based learning based on gender. It means both Challengebased and Activity-based learning are gender friendly.

Table 5 reveals that pre-interest mean and standard deviation scores for male students in the Challenge-based group are 2.85 and 0.32 , while that of females in the same group are 2.84 and 0.33. Also, posttest interest mean and standard deviation scores for males in the Challenge-based group are 3.01 and 0.42 with a mean gain of 0.16 , while that of females in the same group are 3.01 and 0.47 with a mean gain of 0.17. Similarly, pre-interest mean and standard deviation scores for males in the Activity-based group are 2.93 and 0.29 , while that of females in the same group are 2.93 and 0.24 . Again, posttest interest mean and standard deviation scores for males in the Activity-based group are 3.03 and 0.38 , while that of females in the same group are 3.03 and 0.39 with the same mean gain score of 0.10 .

Table 3.Mean and Standard Deviation of Achievement Scores of Students Taught Furniture Craft on Method and Gender

\begin{tabular}{ccccccccc}
\hline Method & Gender & & Pretest Score & \multicolumn{3}{c}{ Posttest Score } & Mean \\
\hline Challenge-based & Male & $\mathrm{N}$ & Mean & SD & Mean & SD & Gain/Loss \\
& & & 32 & 35.59 & 8.18 & 63.91 & 22.09 & +28.32 \\
Learning & Female & 7 & 31.43 & 10.99 & 69.57 & 25.98 & +38.14 \\
& & & & & & & & \\
Activity-based & Male & 24 & 27.92 & 11.82 & 31.79 & 6.59 & +3.87 \\
Learning & Female & 5 & 25.80 & 7.39 & 26.20 & 8.67 & +0.40 \\
\hline
\end{tabular}


Table 4.Analysis of Covariance (ANCOVA) of Students Mean Achievement Scores Based on Method and Gender Tests of Between-Subjects Effects Dependent Variable: Posttest

\begin{tabular}{lrrrrr}
\hline Source & Type III Sum of Squares & df & Mean Square & F & Sig. \\
\hline Corrected Method & $23390.806^{\mathrm{a}}$ & 4 & 5847.701 & 18.036 & .000 \\
Intercept & 13600.604 & 1 & 13600.604 & 41.948 & .000 \\
Pretest & 50.887 & 1 & 50.887 & .157 & .693 \\
Method & 14961.603 & 1 & 14961.603 & 46.146 & .000 \\
Gender & 21.246 & 1 & 21.246 & .066 & .799 \\
method $*$ & & & & .422 & .518 \\
Gender & 136.811 & 1 & 136.811 & & \\
Error & 20426.179 & 63 & 324.225 & & \\
Total & 207183.000 & 68 & & & \\
Corrected Total & 43816.985 & 67 & & &
\end{tabular}

The third hypothesis was there is no significant difference in the interest scores of male and female students taught furniture craft technology with Challenge-based and those taught with an activity-based learning approach based on gender. Table 6 indicates that F-ratio (0.001) with associate probability (sig (2tailed $)(p=0.993)$ under gender is greater than significant level (0.05) postulated. Hence, the alternative hypothesis was upheld. Therefore, there is no significant difference between the mean interest scores of students taught furniture craft with Challenge-based learning and those taught with Activity-based learning based on gender. This shows that both groups are gender friendly.

Table 5. Mean and Standard Deviation of Interest Scores of Students Taught Furniture Craft on Method and Gender

\begin{tabular}{|c|c|c|c|c|c|c|c|}
\hline \multirow[t]{2}{*}{ Method } & \multirow[t]{2}{*}{ Gender } & \multicolumn{3}{|c|}{ Pre-Interest Score } & \multicolumn{2}{|c|}{ Post Interest Score } & \multirow{2}{*}{$\begin{array}{c}\text { Mean } \\
\text { Gain/Loss }\end{array}$} \\
\hline & & $\mathrm{N}$ & Mean & SD & Mean & SD & \\
\hline Challenge-based & Male & 32 & 2.85 & 0.32 & 3.01 & 0.42 & +0.16 \\
\hline Learning & Female & 7 & 2.84 & 0.33 & 3.01 & 0.47 & +0.17 \\
\hline Activity-based & Male & 24 & 2.93 & 0.29 & 3.03 & 0.38 & +0.10 \\
\hline Learning & Female & 5 & 2.93 & 0.24 & 3.03 & 0.39 & +0.10 \\
\hline
\end{tabular}

Table 6. Analysis of Covariance (ANCOVA) of Students' Mean Interest Scores Based on Method and Gender Tests of Between-Subjects Effects

\begin{tabular}{lccccc}
\hline $\begin{array}{l}\text { Dependent Variable: Post Interest } \\
\text { Source }\end{array}$ & $\begin{array}{c}\text { Type III Sum } \\
\text { of Squares }\end{array}$ & df & Mean Square & F & Sig. \\
\hline Corrected Method & $.346^{\mathrm{a}}$ & 4 & .087 & .519 & .722 \\
Intercept & 8.682 & 1 & 8.682 & 52.056 & .000 \\
Pre interest & .226 & 1 & .226 & 1.353 & .249 \\
Method & .021 & 1 & .021 & .126 & .724 \\
Gender & .000 & 1 & .000 & .001 & .975 \\
method * gender & $1.319 \mathrm{E}-005$ & 1 & $1.319 \mathrm{E}-005$ & .000 & .993 \\
Error & 10.507 & 63 & .167 & & \\
Total & 612.547 & 68 & & & \\
Corrected Total & 10.853 & 67 & & & \\
\hline R Squared $=.032$ (Adjusted R Squared $=-.030)$ & & & &
\end{tabular}

a. R Squared $=.032$ (Adjusted R Squared $=-.030$ ) 
Findings revealed that Challenge-based learning is more beneficial in enhancing the cognitive performance of the students in furniture craft than Activity-based learning. These findings imply that Challenge-based learning is more effective than Activity-based learning in enhancing students' achievement in furniture craft. The findings are in line with Akor [12] and Pekene [13] who in their study revealed that students taught with Challengebased learning performed significantly better than those taught with Activity-based learning in physics. The findings further revealed that Challenge-based learning has a beneficial impact on academic achievement which is similar to Nekang [14] who reported in his study that implementing Challenge-based learning in teaching trigonometry students increased student achievement in trigonometry compared to students taught with Activitybased learning.

One reasonable reason for the success of Challenge-based learning is the active participation of students in the learning process through a cooperative and intensive way, clarifying, probing and questioning as the students manipulate the materials and tools given to them. The Analysis of covariance indicates that there is a significant difference between the mean achievement scores of students taught furniture craft with Challengebased learning and those taught with Activitybased learning in favor of Challenge-based learning groups with a high mean gain score of 30.07 .

The findings showed that the group taught furniture craft with Challenge-based learning had a mean interest score of 2.84 in pre-test and a mean interest score of 3.01 in the post-test while the group taught furniture craft with Activity-based learning had a mean interest score of 2.93 in the pre-test and a posttest mean of 3.03. This shows that the group taught using a Challenge-based model has a mean gain interest score of 0.17 while the Activity-based learning group has a mean gain interest score of 0.10 . This implies that both models improve students' interest in furniture craft agreeing with the studies conducted by Obi [15] and [16]. The Analysis of Covariance showed that there is no significant difference between the mean interest scores of students taught furniture craft with Challenge-based learning and those taught with Activity-based learning.

Findings reveal that male students taught furniture craft with Challenge-based learning had a mean score of 35.59 in the pre-test and a mean score of 63.91 in the post-test while the female taught furniture craft with the same models had a mean score of 31.43 in the pretest and a mean score of 69.57 in the post-test but in the Activity-based learning, the male students had a mean score of 27.92 in the pretest and a mean score of 31.79 in the post-test while the female counterpart had a mean score of 25.80 in the pre-test and a mean score of 26.20 in the post-test. The statistics show that both male and female students in Challengebased learning and Activity-based learning groups have almost the same mean scores. This implies that both models are gender friendly. The Analysis of covariance shows that there is no significant difference between the mean achievement scores of students taught furniture craft with Challenge-based learning and those taught with Activity-based learning based on gender.

Finding shows that male students taught furniture craft with Challenge-based learning had a mean score of 2.85 in the pre-test and a mean interest score of 3.01 in the post-test while the female counterpart had a mean interest score of 2.84 in the pre-test and a mean interest score of 3.01 in the post-test but in the Activity-based learning, the male had a mean interest score of 2.93 in the pre-test and 3.03 in the post-test while the female counterpart had a mean interest score of 2.93 in the pre-test and 3.03 in the post-test. This shows that both male and female students in the Challenge-based and Activity-based learnings are equal in their interest scores, an indication that Challengebased and Activity-based learnings are gender 
friendly. The analysis of covariance showed that there is no significant difference between the mean interest scores of students taught furniture craft with Challenge-based learning and those taught with Activity-based learning based on gender.

\section{CONCLUSION}

This study evaluates the effect of Challenge-based and Activity-based learning strategies on the psychomotor performance of technical college students and interest in furniture craft in Zamfara and Katsina State. The study revealed that Challenge-based learning is more effective in improving students' academic achievement and retention but that both Challenge-based and Activitybased learning approaches arouse and sustain male and female students' interest in furniture craft. These results, therefore, showed that Challenge-based and Activity-based learning approaches are a viable alternative to the teacher-centered method of teaching furniture craft. Instructional methods such as Challengebased and Activity-based learning approaches allow technical teachers to engage students in the real world of classroom exercises. It allows students to develop valuable thinking skills and acquire an understanding of the technology world. Thus, if Challenge-based and Activitybased learning approaches are adopted to teach furniture craft in technical colleges, students will, undoubtedly, be equipped with knowledge and skills in furniture craft as well as perform and cope more effectively with requisite furniture craft skills to work in the industry, for self-reliance and present world of work.

Based on the findings of this study, the following recommendations are made:(1) The study proposes the teaching/learning of furniture crafts through Challenge and Activitybased learning, (2) the National Board of Technical Education (NBTE) should consider the evaluation of the furniture crafts curriculum with a purpose to implementing Challengebased and Activity-based learning into the teaching of furniture crafts, and (3) Seminars, workshops and in-service programs should be organized by all examination boards (NABTEB and NBTE) to enlighten technical teachers and support their knowledge and skills on the use of the Challenge-based and Activity-based learning approaches for improving students' performance in furniture craft.

\section{REFERENCES}

[1] Federal Republic of Nigeria, National Policy on Education. 4th Edition. 2014.

[2] C. Blakemore and G. Robbie, History of Interior Design \& Furniture: From Ancient Egypt to Nineteenth-Century Europe. New York, 2016.

[3] M. Okoro, O, Principles and Methods in Vocational and Technical Education. Nsukka: University Trust Publishers, 2012.

[4] T. C. Francis, "Workshop Organization, Safety and Gender Equality in Technical and Vocational Education at Secondary School Level," in Workshop organized by South East Zone of National Association of Teachers of Technology held at FCE (T) Umunze, 2013.

[5] D. A. Sudjimat and L. C. Permadi, "Effect of Work-Based Learning Model on Students' Achievement Motivation," J. Pendidik. Teknol. dan Kejuru., vol. 25, no. 2, pp. 204-212, Oct. 2019, doi: 10.21831/JPTK.V25I2.24416.

[6] C. Ogbunanya, T and A. Fakorede, S, O, "Effect of Learning Mode on the Psychomotor Achievement of Automobile Technology Students In Technical Colleges. In Nworgu B.G (Ed.).Education in the Information Age: Global Challenges and Enhancement Strategies," in 1st International Conference of the Faculty of Education, University of Nigeria, Nsukk, 2008.

[7] L. F. Johnson, R. S. Smith, J. T. Smythe, and R. K. Varon, Challenge - Based Learning: An Approach for Our Time. Austin, Texas: The New Media Consortium, 2009.

[8] D. G. Myers, Social Psychology, 7th ed. New York: The McGraw-Hill Companies, Inc., 2002.

[9] O. M. Okoro, Principles and Methods in Vocational and Technical. Nsukka: University Trust Publishers, 2008. 
[10] C. Obodo, G, "Generating Students' Interest in Mathematics," in NMC/PTDF Workshop for Secondary Schools Teachers 8th-14th February, 2014.

[11] V. F. A. Harbor-Peters, "Although \& Interest of Students to the Mathematical Science in Nigeria," in The Mathematical Science Education Summit 2002 Organized by NMC Abuja, 2002.

[12] R. Akor, "Students Under Achievement in Vocational Technical Subjects at Post Primary Schools Suggested," Remedies Teach. Educ. J., vol. 2, no. 1, pp. 22-27, 2010

[13] D. J. Pekene, "Effect of Greeno and Mettes et al Problem Solving Models on Students Achievement in Physics," $J$. Sci. Teach. Assoc. Niger., vol. 37, no. 1, pp. 39-43, 2012.
[14] F. N. Nekang, "Differential Effects of Activity-Based and Challenge-Based Learning Method on Male and Female Students' Achievement and Interest in Trigonometry in Cameroon," University of Nigeria, 2011.

[15] C. N. Obi, "Effects of Two Problem Solving Models on Students Achievement and Interest on Word Problems in Algebra," University of Nigeria, 2013.

[16] B. C. Alio, "Polya's Problem Solving Strategy in Secondary School Students' Achievement and Interest in Mathematics," University of Nigeria, 2007. 